\title{
The 21st-Century Professional Leadership Standards of Secondary School Administrators in Nakhon Nayok, Thailand
}

\author{
Halima M. Iskak ${ }^{1} \&$ Mark Anthony C. Pa-alisbo ${ }^{2}$ \\ ${ }^{1}$ Candidate, Master of Education, St. Theresa International College, Nakhon Nayok, Thailand \\ ${ }^{2}$ Faculty of Education, St. Theresa International College, Nakhon Nayok, Thailand \\ Correspondence: Mark Anthony Cenas Pa-alisbo, Lecturer, Faculty of Education, St. Theresa International \\ College, Ongkharak, Nakhon Nayok, Thailand, 26120. E-mail: markanthony@stic.ac.th
}

Received: August 10, 2019

Accepted: September 4, 2019

Online Published: September 20, 2019

doi:10.5539/jel.v8n5p175

URL: https://doi.org/10.5539/jel.v8n5p175

\begin{abstract}
The 21 st Century has brought a lot of challenges in developing the professional leadership characteristics of school leaders. Their roles are no longer limited in implementing educational policies and objectives but have become responsible for raising the generations and qualifying them in a rapidly changing era. However, in Thailand, it was observed that there were Thai principals and school leaders who were not adequately trained for school leadership.

This descriptive research surveyed the profile of the school administrators of secondary schools in Nakhon Nayok, Thailand as well as their level of practice of the 21 st-Century professional leadership standards. A questionnaire checklist adapted from the frameworks of Kelly Lambert (2001) and The Wallace Foundation (2013) was used to gather data.

Data analysis showed that the school administrators are females, with master's degrees, 55 years and older, and have few years of administrative experience. Further, they highly practiced the different 21 st-century professional leadership standards; however, these were not influenced by their profile. Lastly, it was found out that there were no significant differences in the level of practice of the different 21 st-century professional leadership standards as indicated by the profile indicators of the school administrators.
\end{abstract}

Keywords: cultural, human resource, instructional, managerial, professional leadership standards, school administrators, strategic

\section{Introduction}

The 21st century has brought heightened expectations and mounting demands for school administrators particularly those working in the multicultural environment of international schools in the global context (Yusoff, Manaf, \& Halim, 2009). According to a study conducted by Think Strategic (2001), $21^{\text {st }}$-century school leaders face the challenging task of molding the minds of young learners positively, think strategically about the school goals to achieve them, and consistently hold group members to high standards of performance.

One kind of leadership that has constantly been pressured to deliver are school principals whose roles are no longer limited in implementing educational policies and objectives but have become responsible for raising the generations and qualifying them in a rapid changing era. However, there no specific leadership styles and strategies identified to be more effective than other strategies. It all depends on the learning environment, the school administrators' personality, experience and training, social and economic context, technology, and others.

Professional standards for principals have been developed, and benchmarking and comparison are at the heart of the new performance assessment (Møller, 2009). Leadership standards are particularly important in decision making. After a decision is made, an organization faces the problem of implementation on how to get things done in timely and effective way. Implementation is concerned with leadership standards on how leader influences behaviour, changes the course of event, and overcomes resistance. They are crucial in implementing decisions successfully and affect the methods of teaching of teachers, administrators and the decision-making process in the management of the school. On the other hand, school improvement is greatly affected by leadership standards for administrators to contribute greatly to the direction that schools take in achieving their goals. 
It has been observed in Thailand that there were Thai school administrators who were inadequately trained for school leadership. This resulted to poor performance due to lack of strategies in management and knowledge to govern an organization which negatively affects education in particular and national development in general. In the context of Nakhon Nayok, observation revealed that some administrators who still used traditional approaches of leadership which were no longer in sync with dynamic educational demands of the present. And due to the demands of globalization, The Association of Southeast Asian Nations (ASEAN) integration and technology advancement in education, school administrators need to develop the desired 21st Century professional leadership standards which prompted the researcher in conducting the study.

\section{Methods and Materials}

This was a descriptive research which surveyed the level of practice of the 21st-century professional leadership standards among secondary school administrators from selected secondary schools in Nakhon Nayok, Thailand. The 100 school administrators consisted of the directors, assistant directors, headmasters, assistant headmaster, principals and department heads.

Utilizing a questionnaire checklist adapted from the frameworks of Kelly Lambert (2001) and The Wallace Foundation (2013), determined the demographic profile of the respondents which included age, gender, educational attainment and years of experience. This questionnaire was translated into Thai and being tested for face validity and reliability through Cronbach Alpha. On the other hand, the 21st-century professional leadership standards included strategic, instructional, cultural, human resource, and managerial.

\section{Results}

\subsection{Profile of the Respondents}

The school administrators of selected secondary schools of Nakhon Nayok, Thailand are females, with master's degrees, aged 55 years and older and with 5 to 10 years of administrative experience. This implies that women school administrators in the secondary schools in Nakhon Nayok, Thailand has broken traditional male dominance in leadership, however, Barbuto, Fritz, Matkin and Marx (2007) found out that gender produced a small direct effect on leadership behaviors. Moreover, the school administrators possessing post-baccalaureate degrees ushers better leadership performance as Reyes (2018) cited that their advanced knowledge gives them greater in-depth and analytical knowledge and that educational attainment positively predicts managerial performance. Having a few years of administrative experience could have resulted in the inadequacy of necessary leadership skills since work experience provides tacit, practical knowledge less frequently provided by formal education (Reyes, 2018).

\subsection{Level of Practice of 21st Century Professional Leadership Standards}

The table below illustrates that the school administrators perceived that they have a high level of practice in the different strands of professional leadership standards with an overall mean of 4.03. Specifically, they perceived that they have a high level of practice in strategic leadership with a mean of 4.10. Being a strategic leader, one fills the gap between the need for new possibilities and the need for practicality by providing a prescriptive set of habits and Elenkov, Judge and Wright (2005) found out that strategic leadership behaviors have a strong positive relationship with executive influence. On the other hand, the school administrators perceived that they have a high level of practice in cultural leadership. This kind of leadership is needed in organizations with diverse populations because this is about developing the relationships leaders need to progress in their careers, through the creation of professional networks, mentoring programs and collaborative projects.

\subsection{Relationship Between the Profile of the School Administrators and Their Level of Practice of the 21st Century Professional Leadership Standards}

Data analysis using spearman rho found out that the level of practice of 21st-century professional leadership standards by the school administrators is independent of their age, gender, educational attainment and years of experience. Data analysis showed that the school administrators are females, with master's degrees, 55 years and older, and have few years of administrative experience. This negated the findings of Selvarajah, Meyer and Donovan (2013) that age and gender were demonstrated as key differentiating factors in the perceptions of Thai managers with regards to the demonstration of the professional leadership standards. Moreover, these findings disagreed with Taylor (1998) when he found out that gender, age, and education predicted a significant magnitude of team effectiveness. 


\subsection{Differences Among the 21st-Century Professional Leadership Standards of School Administrators when Grouped According to Their Profile}

Analysis of variance showed that there were no statistically significant differences between and among the different levels of practice of strategic, instructional, cultural, human resource and managerial leadership when grouped according to age, gender, educational attainment, and administrative experience.

Table 1. Level of practice of 21 st-century professional leadership standards

\begin{tabular}{llll}
\hline 21st Century Professional Leadership Standards & Mean & sd & Description \\
\hline 1) Strategic Leadership & 4.10 & 0.680 & High \\
2) Instructional Leadership & 4.08 & 0.742 & High \\
3) Cultural Leadership & 3.96 & 0.820 & High \\
4) Human Resource Leadership & 4.01 & 0.847 & High \\
5) Managerial Leadership & 3.98 & 0.777 & High \\
Overall Mean & 4.03 & 0.773 & High \\
\hline
\end{tabular}

Note. Scale: 4.50 to 5.00 means Very High; 3.50 to 4.49 signifies High; 2.50 to 3.49 interprets Moderate; 1.50 to 2.49 means Low; and lastly; 1.00 to 1.49 for Very Low.

\section{Discussion}

This study was conducted among school administrators of secondary schools in Nakhon Nayok, Thailand. Demographically, they are females, possessed post-baccalaureate degrees, in their late adulthood, and have few years of administrative experience. The school administrators indicated that they highly practiced the different 21st-century professional leadership standards along cultural, institutional, strategic, human resource and managerial, however, further analysis showed that this was not influenced by their profile. It was also found out that their level of practice of the various 21 st-century professional standards did not significantly differ when grouped according to their profile.

Based on the results of this study, the school administrators of the secondary schools can be encouraged to pursue post-baccalaureate courses related to school leadership and administration. Also, a mentorship program for younger prospective school administrators can be considered to bring a younger breed of academic leaders. Leadership practices of school administrators from other parts of Thailand can also be considered. Lastly, other demographic characteristics of school administrators can be included in future researches as well as other dimensions of school administration.

\section{Acknowledgments}

The author wished to extend her sincerest gratitude to her research advisor, Dr. Mark Anthony Pa-alisbo and co-advisor, Dr. Somjate Waiyakarn for the technical assistance in improving the manuscript. She also gave her thanks to the research committee headed by the chairman/external assessor, Dr. Pragob Kunarak; panel members: Dr. Vichian Puncreobutr, Dr, Annop Photisuk, Dr. Nongnuch Suwanaruji, and Dr. Panida Klosawakdi for their constructive comments and suggestions.

\section{References}

Barbuto, J. E., Fritz, S. M., Matkin, G. S., \& Marx, D. B. (2007). Effects of gender, education, and age upon leaders' use of influence tactics and full range leadership behaviors. Sex Roles, 56(1-2), 71-83. https://doi.org/10.1007/s11199-006-9152-6

Elenkov, D. S., Judge, W., \& Wright, P. (2005). Strategic leadership and executive innovation influence: an international multi-cluster comparative study. Strategic Management Journal, 26(7), 665-682. https://doi.org/10.1002/smj.469

Lunenburg, F., \& Ornstein, A. (2008). Educational Administration (5th ed.). Sam Houston State University.

Møller, J. (2009). School leadership in an age of accountability: Tensions between managerial and professional accountability. Journal of Educational Change, 10(1), 37-46. https://doi.org/10.1007/s10833-008-9078-6

Payden, B. L. (1997). The relationship between perceived leadership behaviors and job satisfaction based on age, gender, and education level variables. Dissertation Abstracts International (Section A: Humanities \& Social Sciences), 57(7-A), 3127.

Reyes, G. V. (2018). Performance of academic middle managers and the attainment of their trilogic functions. 
Asia Pacific Journal of Multidiciplinary Research. Retrieved from http://www.apjmr.com/apjmr-vol-7-no-3/

Selvarajah, C., Meyer, D., \& Donovan, J. (2013). Cultural context and its influence on managerial leadership in Thailand. Asia Pacific Business Review, 19(3), 356-380. https://doi.org/10.1080/13602381.2012.714630

Taylor, T. R. (1998). Factors influencing the effectiveness of cross-functional work teams in a research and development organization. Dissertation Abstracts International (Section B: The Sciences \& Engineering), 58(10-B), 5685.

The Wallace Foundation. (2013). Recent Leader Standards. Retrieved February 20, 2019 from http://www.wallacefoundation.org

Thomas, B. B. (1996). The relationship of leadership style to teacher leadership preferences. Dissertation Abstracts International (Section A: Humanities \& Social Sciences), 57(1-A), 0064.

Yusoff, S., Manaf, A. R., \& Halim, R. A. (2009). Best Practices in Educational Management and Leadership: Identifying High Impact Competencies for Malaysian School Principals.

\section{Copyrights}

Copyright for this article is retained by the author, with first publication rights granted to the journal.

This is an open-access article distributed under the terms and conditions of the Creative Commons Attribution license (http://creativecommons.org/licenses/by/4.0/). 